\title{
The nutritional status and fluorescence characteristics of maize cultivars with different chlorophyll content and yields
}

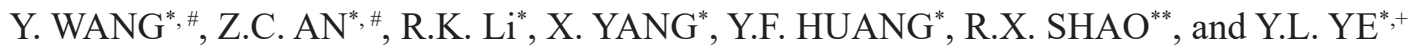 \\ College of Resources and Environment, Henan Agricultural University, Zhengzhou 450002, China* \\ College of Agricultural, Henan Agricultural University, Zhengzhou 450002, China**
}

\begin{abstract}
Chlorophyll (Chl) is generally positively related to corn grain yields; however, light-leaf-colored maize may also achieve high yields. Thus, Chl is seemingly not a key parameter for maize producers. Modern maize cultivars (55) were divided into four types, based on grain yields and ear leaf SPAD readings. The results revealed that there was no correlation between the SPAD readings and corn grain yields across different maize cultivars. High-yield maize possessed higher nitrogen, phosphorus, and potassium accumulation and utilization compared to that of low-yield maize; the N-transport efficiency of low yield and high SPAD was the lowest among various types of maize. Under normal conditions, parameters determining the high yield of maize in a sequence was leaf dry mass, Chl fluorescence indices, and light absorption flux per leaf cross section. A higher absorption flux, accompanied by high energy dissipation ratios, reduced the difference of trapped transport flux between high-SPAD and low-SPAD maize at high yield levels. At the low yield level, a higher absorption flux per reaction center compensated for the loss of PSII reaction center numbers in low-SPAD maize.
\end{abstract}

Additional key words: chlorophyll fluorescence; cultivar; maize; nutrient; SPAD.

\section{Introduction}

Maize (Zea mays L.) is an economically important crop due to its widespread commercial production and utilization. Nutrient deficiencies and imbalances during the growing season can lead to a yield reduction. Crop yields are closely related to the uptake and utilization of nutrients, particularly, macroelements, which include $\mathrm{N}, \mathrm{P}$, and $\mathrm{K}$. High-yield maize exhibited a greater N, P, or K uptake efficiency, harvest index, and partial fertilizer productivity in contrast to normal-yield maize (Qi et al. 2013). Higher nutrient accumulation and appropriate nutrient distribution within different plant organs enable maize to improve photosynthesis, while accumulating additional dry matter (Paponov and Engels 2003).

$\mathrm{Chl}$, in its various forms, is the primary photosynthetic pigment found in higher plants. Leaf Chl content is correlated with the concentration of $\mathrm{N}$ in leaves and the $\mathrm{N}$ fertilizer rate (Boegh et al. 2002). The SPAD (Soil and
Plant Analyzer Development) Chl meter was found to be a reliable, quick, and nondestructive tool for the direct measurement of leaf Chl (Mielke et al. 2010). Liu et al. (2016) and Lin et al. (2010) reported that SPAD readings were highly accurate for predicting grain yields. These findings were contradicted by Errecart et al. (2012) and Lindsey et al. (2016), who reported that SPAD readings at early growth stages were not well correlated with yields; however, late season measurements were shown to provide the best prediction of yields. In contrast, Tong et al. (2008) found no significant relationship between SPAD readings and yields following the silking stage. Additionally, Costa et al. (2001) suggested that not every maize cultivar showed a high SPAD-yield correlation, and the correlation coefficients between SPAD readings and grain yields were typically lower. Although, the enhanced Chl content is conducive to the capture of sunlight for leaves, it is not always related to the increased grain production. Tomas and Smart (1993) illustrated four possible types of sustained

$\overline{\text { Received }} 8$ February 2018, accepted 12 September 2018.

${ }^{+}$Corresponding author; email: ylye@henau.edu.cn

Abbreviations: ABS - absorption flux; Chl - chlorophyll; CS - cross-section; DI - dissipated energy flux; ET - electron transport flux; $\mathrm{F}_{0}$ - minimal fluorescence yield of the dark-adapted state; $\mathrm{F}_{\mathrm{M}}-$ maximal fluorescence yield of the dark-adapted state; $\mathrm{F}_{\mathrm{V}}-$ variable fluorescence; HYHS - high yield high SPAD; HYLS - high yield low SPAD; KA - K absorption; KGPE - K grain production efficiency; KHI - K harvest index; LYHS - low yield high SPAD; LYLS - low yield low SPAD; NA - N absorption; NHI - N harvest index; NGPE - N grain production efficiency; PA - P absorption; PGPE - P grain production efficiency; PHI - P harvest index; PI - performance index; RC - reactive center; RE - reduction of end acceptors at PSI electron acceptor side; SPAD - reading of relative leaf chlorophyll content; TKA - total K accumulation; TNA - total N accumulation; TPA - total P accumulation; TR - trapped energy flux TNA - total $\mathrm{N}$ accumulation; TR - trapped energy flux.

Acknowledgements: We are grateful to Dr. Bing Luo (Hansatech Scientific Instruments Co., Ltd.), who guided us in the operation of the Handy-PEA instrument, and assisted with the analysis of the fluorescence data. This work was financially supported by the National Key Research and Development Program of China (No. 2017YFD0200100).

\#These authors contributed equally to this work. 
greenery in leaves. Particularly, two of these appeared to be green but were lacking photosynthetic competence. Conversely, there were abundant Chl-deficient $\mathrm{C}_{3}$ mutants with reduced amounts of light-harvesting proteins in their thylakoid membranes (Havaux and Tardy 1997, Polle et al. 2000). However, the photosynthetic rates, on a per $\mathrm{Chl}$ basis, were higher in Chl-deficient mutants (Tetali et al. 2007). It means that $\mathrm{Chl}$ deficiencies do not necessarily affect the assimilation of $\mathrm{CO}_{2}$ in plants (Li et al. 2013).

In production, leaf color is hardly used as a breeding standard for high yield in maize, and maize cultivars with dark or light leaves can both achieve the same yields. Therefore, how does low Chl produce higher grain yields in maize? Further, why does not high $\mathrm{Chl}$ in maize attain higher grain yields? In this paper, we compared the nutrient utilization efficiencies and photochemical characteristics of leaf PSII in high and low SPAD maize cultivars at two yield levels, and evaluated the impact of leaf color on nutrient absorption, the utilization of corn, and yield formation.

\section{Materials and methods}

Site description: Field experiments were conducted in Changge county $\left(34^{\circ} 27^{\prime} \mathrm{N} 113^{\circ} 34^{\prime} \mathrm{E}\right)$, Henan province, in Central China. During the maize growing season (Fig. 1S, supplement), the average daily air temperature and total precipitation were $29.8^{\circ} \mathrm{C}$ and $487.4 \mathrm{~mm}$, respectively, in 2017 (June-October). Prior to experimentation, soil samples extracted from the upper $20-\mathrm{cm}$ layer were collected for chemical analyses. The soil type was fluvoaquic soil of $\mathrm{pH} 7.4$, with an organic matter content of $18.33 \mathrm{~g} \mathrm{~kg}^{-1}(0-20 \mathrm{~cm})$, total $\mathrm{N}$ of $1.58 \mathrm{~g} \mathrm{~kg}^{-1}$, available $\mathrm{P}$ of $20.83 \mathrm{mg} \mathrm{kg}^{-1}$, and available $\mathrm{K}$ of $142.52 \mathrm{mg} \mathrm{kg}^{-1}$.

Experimental design and management: The proposed study was laid out in a randomized complete block design with three replications. A total of 55 maize cultivars, which are widely cultivated in Huang-Huai-Hai plain, were used for the experiment, with the specific name of maize listed in Table 1S (supplement). Seeds were mechanically sown on 10 June at a hill spacing of $0.60 \times 0.27 \mathrm{~m}$, with 61,725 plants ha ${ }^{-1}$, with the dimensions of each plot being $4 \times 10 \mathrm{~m}$. Nitrogen $\left[180 \mathrm{~kg}(\mathrm{~N}) \mathrm{ha}^{-1}\right]$ in the form of urea was applied in two splits with $50 \%$ at basal and $50 \%$ at the 10 -leaf stage (45 d after sowing). Phosphorus [90 $\mathrm{kg}\left(\mathrm{P}_{2} \mathrm{O}_{5}\right) \mathrm{ha}^{-1}$ ] in the form of calcium superphosphate, and potassium [90 $\left.\mathrm{kg}(\mathrm{KCl}) \mathrm{ha}^{-1}\right]$ were applied as a basal dose. Nicosulfuron and atrazine were applied at 3-leaf stage to control weeds, and thiophanate-methyl and lambda-cyhalothrin were applied at 8-leaf stage to prevent diseases and insects.

Chl measurements: Chl meter readings were obtained using a hand-held dual-wavelength meter (SPAD-502, Minolta Camera Co., Ltd., Japan) from the mid-point of the ear leaf at the maize silking stage ( $75 \mathrm{~d}$ after sowing). Ear leaves of ten consecutive plants in one of the central rows were labeled with small plastic tags, and SPAD value was measured in the morning (08:00-11:00 h).
Leaf Chl $\boldsymbol{a}$ fluorescence was measured for $10 \mathrm{~s}$ using a plant efficiency analyzer (PEA; Hansatech Ltd., King's Lynn, Norfolk, England), which emits light that is centered at a $650 \mathrm{~nm}$ wavelength with an intensity of 3,000 $\mu \mathrm{mol}$ (photon) $\mathrm{m}^{-2} \mathrm{~s}^{-1}$. The fluorescence emission is detected by a high-performance PIN-photodiode with an optical design and filtering that ensures maximal response to longer wavelength fluorescence signals. These measurements were taken from (30 min dark-adapted) ear leaves on the second day after SPAD assay, where five tagged leaves in each plot were measured for each maize cultivar. Each transient was analyzed according to the JIP-test (Appenroth et al. 2001, Li et al. 2017), by utilizing the original data: $\mathrm{F}_{0}$ (minimum fluorescence, when all PSII reaction centers were open), $\mathrm{F}_{\mathrm{M}}$ (maximum fluorescence, when all PSII reaction centers were closed), $\mathrm{V}_{\mathrm{J}}$ (the fluorescence intensities at $2 \mathrm{~ms}$ ). The following equations were used for the quantification of PSII behavior, referring to time zero: (1) the flux ratios, the maximum quantum yield of primary photochemistry $\left(\Phi_{\mathrm{P} 0}\right)$, the efficiency with which a trapped exciton can move an electron into the electron transport chain further than $\mathrm{Q}_{\mathrm{A}}^{-}\left(\Psi_{0}\right)$, the quantum yield of electron transport $\left(\Phi_{\mathrm{Eo}}\right)$ and the quantum yield for the reduction of end acceptors of PSI $\left(\Phi_{\mathrm{Ro}}\right)$ :

$\Phi_{\mathrm{Po}_{0}}=\mathrm{TR}_{0} / \mathrm{ABS}=1-\mathrm{F}_{0} / \mathrm{F}_{\mathrm{M}}$;

$\Psi_{\mathrm{o}}=\mathrm{ET}_{0} / \mathrm{TR}_{0}=1-\mathrm{V}_{\mathrm{J}}$

$\Phi_{\mathrm{Eo}}=\mathrm{ET}_{0} / \mathrm{ABS}=\left[1-\mathrm{F}_{0} / \mathrm{F}_{\mathrm{M}}\right] \times \Psi_{\mathrm{o}} ;$

$\Phi_{\mathrm{Do}}=1-\Phi_{\mathrm{Po}_{\mathrm{o}}}=\mathrm{F}_{0} / \mathrm{F}_{\mathrm{M}}$;

$\Phi_{\mathrm{Ro}}=\mathrm{RE}_{0} / \mathrm{ABS}$,

(2) specific energy fluxes per cross-section (CS) for absorption $\left(\mathrm{ABS} / \mathrm{CS}_{0}\right)$, trapping $\left(\mathrm{TR}_{0} / \mathrm{CS}_{0}\right)$, electron transport $\left(\mathrm{ET}_{0} / \mathrm{CS}_{0}\right)$, dissipation $\left(\mathrm{DI}_{0} / \mathrm{CS}_{0}\right)$, and PSI electron acception $\left(\mathrm{RE}_{0} / \mathrm{CS}_{0}\right)$ :

$\mathrm{ABS} / \mathrm{CS}_{0}=\mathrm{F}_{0}$;

$\mathrm{TR}_{0} / \mathrm{CS}_{0}=\Phi_{\mathrm{Po}_{\mathrm{o}}} \times\left(\mathrm{ABS} / \mathrm{CS}_{0}\right)$

$\mathrm{ET}_{0} / \mathrm{CS}_{0}=\Phi_{\mathrm{Eo}} \times\left(\mathrm{ABS} / \mathrm{CS}_{0}\right)$;

$\mathrm{DI}_{0} / \mathrm{CS}_{0}=\left(\mathrm{ABS} / \mathrm{CS}_{0}\right)-\left(\mathrm{TR}_{0} / \mathrm{CS}_{0}\right)$;

$\mathrm{RE}_{0} / \mathrm{CS}_{0}=\left(\mathrm{ABS} / \mathrm{CS}_{0}\right) \times \Phi_{\mathrm{Ro}}$,

(3) the amount of active PSII reaction centers per excited cross-section $\left(\mathrm{RC} / \mathrm{CS}_{0}\right)$ :

$\mathrm{RC} / \mathrm{CS}_{0}=\left(\mathrm{ABS} / \mathrm{CS}_{0}\right) \times\left(\mathrm{TR}_{0} / \mathrm{ABS}\right) \times\left(\mathrm{RC} / \mathrm{TR}_{0}\right)=$ $=\mathrm{F}_{\mathrm{M}} \times \Phi_{\mathrm{Po}} \times \mathrm{V}_{\mathrm{J}} / \mathrm{M}_{0}$,

(4) the performance index $\left(\mathrm{PI}_{\mathrm{ABS}}\right)$ and total performance index $\left(\mathrm{PI}_{\text {total }}\right)$ of photosynthetic apparatus on absorption basis:

$\mathrm{PI}_{\mathrm{ABS}}=(\mathrm{RC} / \mathrm{ABS}) \times\left[\left(\mathrm{TR}_{0} / \mathrm{ABS}\right) /\left(1-\mathrm{TR}_{0} / \mathrm{ABS}\right)\right] \times$

$\times\left[\left(\mathrm{ET}_{0} / \mathrm{TR}_{0}\right) /\left(1-\mathrm{ET}_{0} / \mathrm{TR}_{0}\right)\right]$;

$\mathrm{PI}_{\text {total }}=\mathrm{PI}_{\mathrm{ABS}} \times\left[\left(\mathrm{RE}_{0} / \mathrm{ET}_{0}\right) /\left(1-\mathrm{RE}_{0} / \mathrm{ET}_{0}\right)\right]$.

Plant sampling and nutrient measurements: At maturity (115 d after sowing), five plants from each plot were sampled, and then dissected into leaf, stem, cob, and grain. These fresh materials were oven dried at $105^{\circ} \mathrm{C}$ for $30 \mathrm{~min}$ and then at $75^{\circ} \mathrm{C}$ until a constant mass was achieved. The grain yield of corn grains was adjusted to $13 \%$ moisture content. The plant materials were ground to pass through a 1-mm mesh screen, and then digested by $\mathrm{H}_{2} \mathrm{SO}_{4}$ and 
$\mathrm{H}_{2} \mathrm{O}_{2}$. The total $\mathrm{N}$ and $\mathrm{P}$ concentration of the digested samples was determined using an automated continuous flow analyzer (Seal, Norderstedt, Germany). The total K concentration of the digested samples was determined with a flame photometer FP-640 (Precision Instrument Co., Ltd., Shanghai, China).

Data analysis: The formula for calculating the absorption and utilization efficiency parameters of the three nutrients $(\mathrm{N}, \mathrm{P}$, and $\mathrm{K}$ ) is identical. The example of $\mathrm{N}$ is introduced as follows:

TNA $\left[\mathrm{kg} \mathrm{ha}^{-1}\right]=$ plant $\mathrm{N}$ concentration $\left[\mathrm{kg} \mathrm{kg}^{-1}\right] \times$ plant dry matter $\left[\mathrm{kg} \mathrm{ha}^{-1}\right]$;

$\mathrm{NA}$ in $100 \mathrm{~kg}$ of grains $[\mathrm{kg}]=\mathrm{TNA}\left[\mathrm{kg} \mathrm{ha}^{-1}\right] /$ corn grain yield $\left[\mathrm{kg} \mathrm{ha}^{-1}\right] \times 100[\mathrm{~kg}]$;

NHI $[\%]=$ grain $\mathrm{N}$ accumulation $\left[\mathrm{kg} \mathrm{ha}^{-1}\right] / \mathrm{TNA}\left[\mathrm{kg} \mathrm{ha}^{-1}\right]$ $\times 100[\%]$;

NGPE $\left[\mathrm{kg} \mathrm{kg}^{-1}\right]=$ corn grain yield $\left[\mathrm{kg} \mathrm{ha}^{-1}\right] / \mathrm{TNA}\left[\mathrm{kg} \mathrm{ha}{ }^{-1}\right]$

where TNA is the total $\mathrm{N}$ accumulation, $\mathrm{NHI}$ is the $\mathrm{N}$ harvest index, NGPE is the $\mathrm{N}$ grain production efficiency. A one-way analysis of variance ( $A N O V A$ ) was applied to assess differences in each parameter using the Statistical Software Package for Social Science (SPSS, version 19.0), and the mean values of the treatments were compared on the basis of the least significant difference test (LSD). The graphs were plotted using the Origin 9.0 software program.

\section{Results}

Maize type classification according to yield and SPAD: There was no clear linear relationship between the yield and SPAD values for different maize cultivars $(\mathrm{y}=33.62 \mathrm{x}$ $+6258.8, p=0.225$; Fig. 1$)$. The 55 maize cultivars were divided into four types based on the grain yield and leaf SPAD (Tables 1, 1S): high yield high SPAD (HYHS), high yield low SPAD (HYLS), low yield high SPAD (LYHS), low yield low SPAD (LYLS). The yield range of highyield type maize was $8,166.4-10,607.5 \mathrm{~kg} \mathrm{ha}^{-1}$, and the range of low-yield types maize was $6,098.3-8,088.7 \mathrm{~kg}$ $\mathrm{ha}^{-1}$ (Table 1). The SPAD range of high-SPAD type maize was 55.9-66.3, and the range of low-SPAD type maize was 43.1-55.5. The mean yield of high-yield type maize was observed to be $18.1 \%$ higher than low-yield type maize, whereas the mean SPAD of high-SPAD type maize was $12.5 \%$ higher than low-SPAD type maize. The overall percentage for the four types of maize was similar.

Dry mass distribution of different maize types: The aboveground biomass of high-yield type maize was significantly higher than that for low-yield type maize at plant maturity stage (Fig. 2). No significant stem dry matter change was observed among the different types of maize. The leaf dry matter of the HYLS maize was significantly higher than that of the LYHS and LYLS maize. The mean corn dry matter of the HYHS and HYLS maize was $12.0 \%$ heavier than that of the LYHS and LYLS maize.

Nutrient uptake and utilization of different maize types: Plant TNA and TPA was statistically similar among the four types of maize (Table 2). The plant TKA of the high-yield type maize was $11.7 \%$ higher, in contrast to the low-yield type maize, whereas, the LYHS was significantly lower than that of the two HY types. The NHI in the highyield type maize was higher than that of low-yield type, furthermore, the NHI in HYLS was $13.8 \%$ higher than that of LYHS, which constituted a significant difference. Nevertheless, no significant variations in PHI and $\mathrm{KHI}$ were observed among the different maize types.

The NA in $100 \mathrm{~kg}$ of grains was shown as LYLS > LYHS $>$ HYLS $>$ HYHS, where LYLS was significantly higher than that of HYHS (Table 3). Similarly, the PA and KA in $100 \mathrm{~kg}$ of grains of LY type maize was higher than that of HY type maize. The trend of grain nutrients

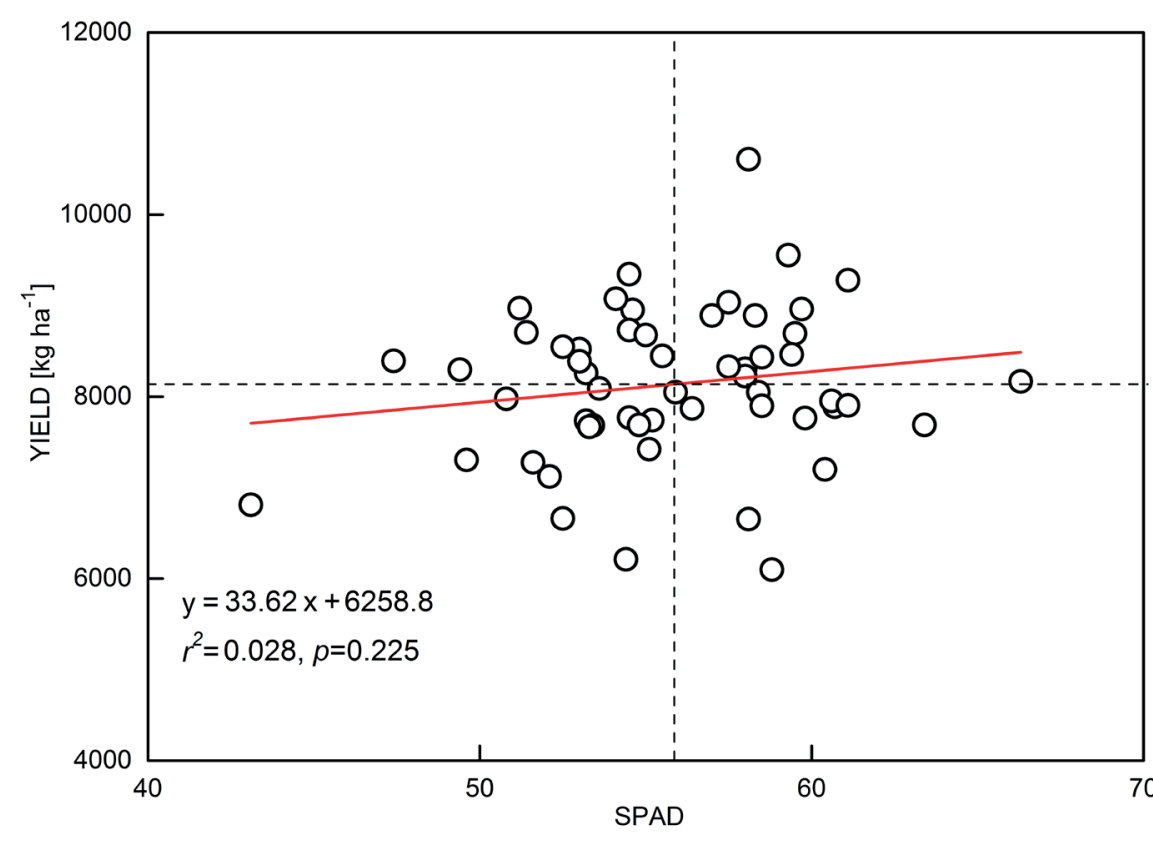

Fig. 1. Relationships between the yield and SPAD of 55 modern maize cultivars. Values are means $(n=3)$. 
Table 1. Classification of 55 maize cultivars based on yield and SPAD. Different letters in the same column denote significant differences according to the LSD post-hoc test $(p<0.05)$ between different types of maize cultivars.

\begin{tabular}{lllllll}
\hline Type & $\begin{array}{l}\text { Yield }\left[\mathrm{kg} \mathrm{ha}^{-1}\right] \\
\text { Range }\end{array}$ & Mean & $\begin{array}{l}\text { SPAD } \\
\text { Range }\end{array}$ & Mean & Count & Percentage [\%] \\
\hline HYHS & $8,166.4-10,607.5$ & $8,845.8^{\text {a }}$ & $57.0-66.3$ & $59.1^{\text {a }}$ & 14 & 25.5 \\
HYLS & $8,259.1-9,346.0$ & $8,865.0^{\text {a }}$ & $47.4-55.5$ & $52.8^{\text {b }}$ & 14 & 25.5 \\
LYHS & $6,098.3-8,050.0$ & $7,585.1^{\text {b }}$ & $55.9-63.4$ & $59.3^{\text {a }}$ & 12 & 21.8 \\
LYLS & $6,209.3-8,088.7$ & $7,410.2^{\text {b }}$ & $43.1-55.2$ & $52.5^{\text {b }}$ & 15 & 27.2 \\
\hline
\end{tabular}

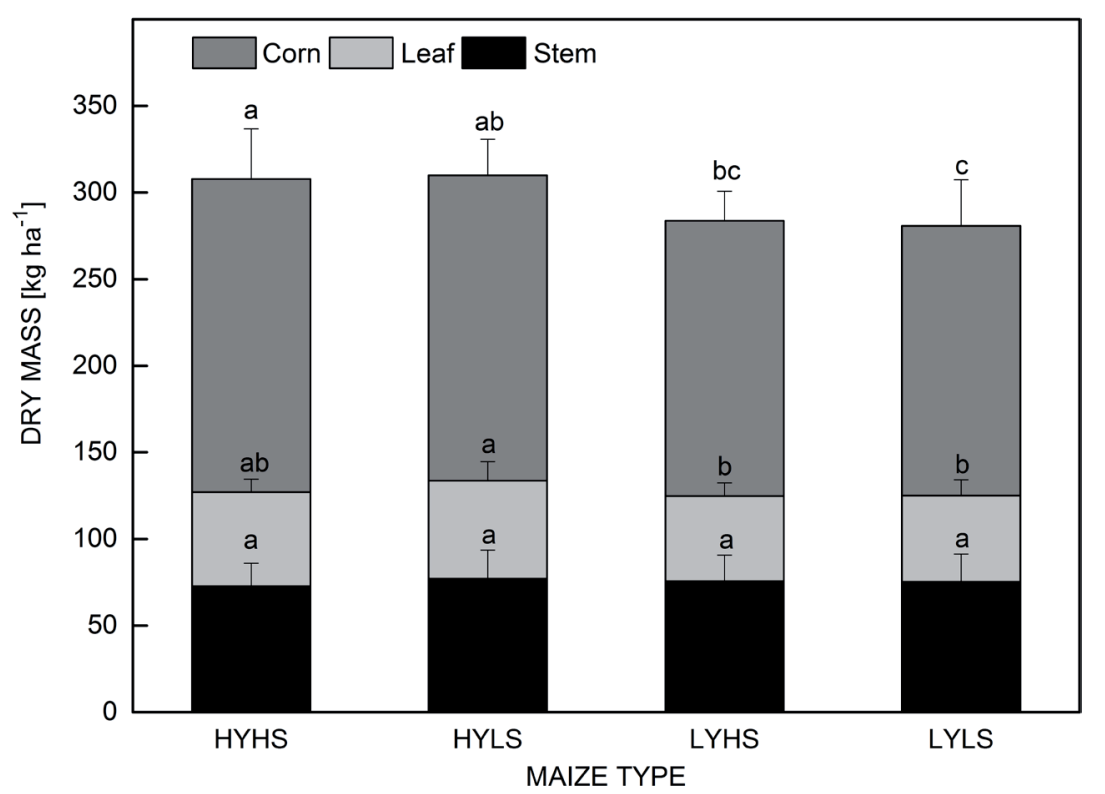

Fig. 2. Dry matter accumulation and distribution in different types of maize cultivars. Additional letters for the same organ denote significant differences according to the LSD post-hoc test $(p<0.05)$ between the different types of maize cultivars. Values are means $\pm \mathrm{SD}(n=3)$.

Table 2. N, P, and K uptake and utilization for different types of maize cultivars. TNA, total N accumulation; NHI - N harvest index; TPA - total P accumulation; PHI - P harvest index; TKA - total K accumulation; KHI - K harvest index. Values are means \pm SD $(n=3)$. Different letters in the same column denote significant differences according to the LSD post-hoc test $(p<0.05)$ between the different types of maize cultivars.

\begin{tabular}{lllllll}
\hline Type & TNA $\left[\mathrm{kg} \mathrm{ha}^{-1}\right]$ & NHI [\%] & TPA $\left[\mathrm{kg} \mathrm{ha}^{-1}\right]$ & PHI [\%] & TKA [kg ha $\left.{ }^{-1}\right]$ & KHI [\%] \\
\hline HYHS & $225.6 \pm 30.7^{\mathrm{a}}$ & $51.4 \pm 8.1^{\mathrm{ab}}$ & $102.4 \pm 17.0^{\mathrm{a}}$ & $58.1 \pm 5.7^{\mathrm{a}}$ & $456.9 \pm 72.9^{\mathrm{a}}$ & $21.4 \pm 4.0^{\mathrm{a}}$ \\
HYLS & $227.2 \pm 41.3^{\mathrm{a}}$ & $52.0 \pm 7.3^{\mathrm{a}}$ & $109.0 \pm 16.2^{\mathrm{a}}$ & $57.7 \pm 8.2^{\mathrm{a}}$ & $444.0 \pm 71.3^{\mathrm{a}}$ & $24.1 \pm 5.6^{\mathrm{a}}$ \\
LYHS & $214.5 \pm 49.4^{\mathrm{a}}$ & $45.7 \pm 7.2^{\mathrm{b}}$ & $103.1 \pm 14.9^{\mathrm{a}}$ & $56.0 \pm 7.8^{\mathrm{a}}$ & $387.9 \pm 56.3^{\mathrm{b}}$ & $22.7 \pm 4.2^{\mathrm{a}}$ \\
LYLS & $213.8 \pm 41.0^{\mathrm{a}}$ & $47.5 \pm 5.8^{\mathrm{ab}}$ & $99.7 \pm 21.2^{\mathrm{a}}$ & $58.19 .0^{\mathrm{a}}$ & $418.4 \pm 74.4^{\mathrm{ab}}$ & $21.8 \pm 3.5^{\mathrm{a}}$ \\
\hline
\end{tabular}

Table 3. N, P, and K absorption efficiency of grains for different types of maize cultivars. NA - N absorption; PA - P absorption; KA - K absorption; NGPE - N grain production efficiency; PGPE - P grain production efficiency; KGPE - K grain production efficiency. Values are means $\pm \operatorname{SD}(n=3)$. Different letters in the same column denote significant differences according to the LSD post-hoc test $(p<0.05)$ between the different types of maize cultivars.

\begin{tabular}{|c|c|c|c|c|c|c|}
\hline Type & $\begin{array}{l}\text { NA in } 100 \mathrm{~kg} \text { of } \\
\text { grains }[\mathrm{kg}]\end{array}$ & NGPE $\left[\mathrm{kg} \mathrm{kg}^{-1}\right]$ & $\begin{array}{l}\text { PA in } 100 \mathrm{~kg} \text { of } \\
\text { grains }[\mathrm{kg}]\end{array}$ & PGPE $\left[\mathrm{kg} \mathrm{kg}^{-1}\right]$ & $\begin{array}{l}\text { KA in } 100 \mathrm{~kg} \text { of } \\
\text { grains }[\mathrm{kg}]\end{array}$ & $\mathrm{KGPE}\left[\mathrm{kg} \mathrm{kg}^{-1}\right]$ \\
\hline HYHS & $2.56 \pm 0.26^{\mathrm{b}}$ & $40.0 \pm 4.4^{\mathrm{a}}$ & $1.16 \pm 0.20^{\mathrm{b}}$ & $89.0 \pm 15.4^{\mathrm{a}}$ & $5.05 \pm 0.74^{\mathrm{ab}}$ & $19.8 \pm 3.5^{\mathrm{a}}$ \\
\hline HYLS & $2.64 \pm 0.44^{\mathrm{ab}}$ & $39.6 \pm 5.2^{\mathrm{ab}}$ & $1.26 \pm 0.20^{\mathrm{ab}}$ & $81.7 \pm 13.1^{\mathrm{ab}}$ & $5.02 \pm 0.76^{\mathrm{b}}$ & $20.1 \pm 3.9^{\mathrm{a}}$ \\
\hline LYHS & $2.87 \pm 0.57^{\mathrm{ab}}$ & $37.0 \pm 6.3^{\mathrm{ab}}$ & $1.38 \pm 0.30^{\mathrm{a}}$ & $75.7 \pm 15.2^{\mathrm{b}}$ & $5.17 \pm 0.67^{\mathrm{ab}}$ & $19.5 \pm 3.5^{\mathrm{a}}$ \\
\hline LYLS & $2.91 \pm 0.54^{\mathrm{a}}$ & $35.3 \pm 5.4^{\mathrm{b}}$ & $1.34 \pm 0.24^{\mathrm{ab}}$ & $77.2 \pm 13.6^{\mathrm{b}}$ & $5.58 \pm 0.69^{\mathrm{a}}$ & $18.1 \pm 3.0^{\mathrm{a}}$ \\
\hline
\end{tabular}




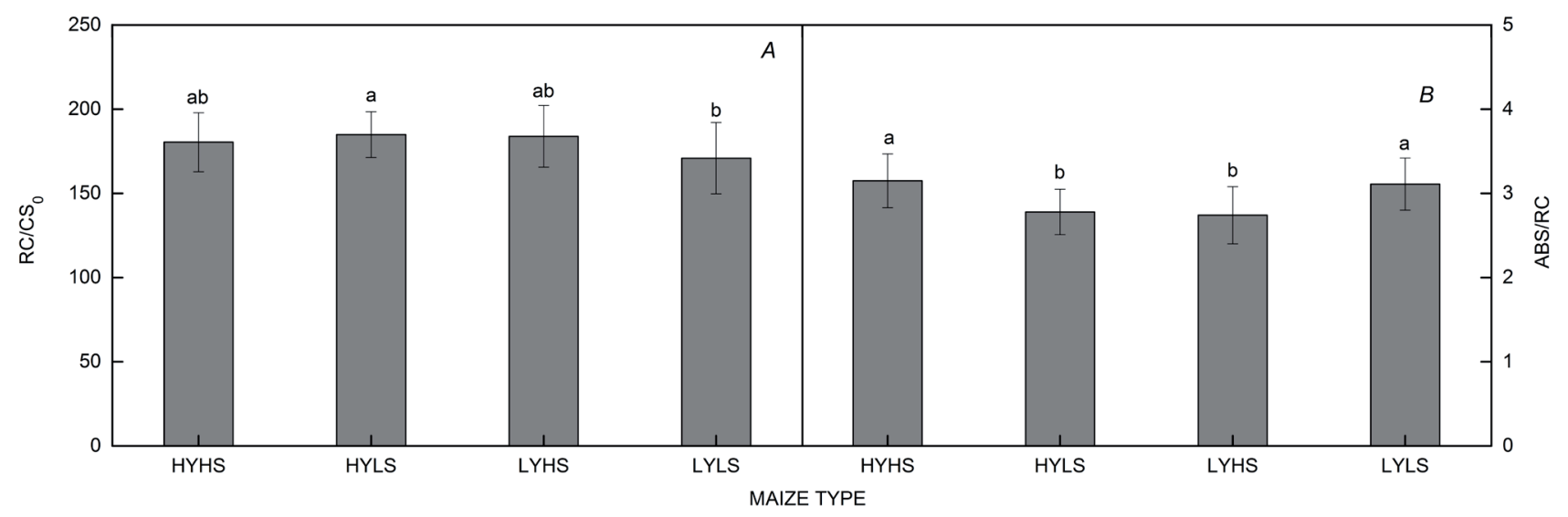

Fig. 3. (A) Number of active PSII reaction centers (RC) per cross-section $\left(\mathrm{CS}_{0}\right)$ and $(B)$ absorption flux (ABS) per PSII reaction center in different types of maize cultivars. Additional letters denote significant differences according to the LSD post-hoc test $(p<0.05)$ between the different types of maize. Values are means $\pm \mathrm{SD}(n=3)$.

Table 4. Specific energy fluxes per cross section (CS) for different types of maize cultivars. ABS/CS - absorption flux per cross section (CS); $\mathrm{DI}_{0} / \mathrm{CS}_{0}$ - dissipated energy flux per $\mathrm{CS} ; \mathrm{TR}_{0} / \mathrm{CS}_{0}$ - trapped energy flux per $\mathrm{CS} ; \mathrm{ET}_{0} / \mathrm{CS}_{0}$ - electron transport flux per $\mathrm{CS}_{2} \mathrm{RE}_{0} / \mathrm{CS}_{0}$ - reduction of end acceptors at PSI electron acceptor side per CS. Values are means $\pm \operatorname{SD}(n=3)$. Different letters in the same column denote significant differences according to the LSD post-hoc test $(p<0.05)$ between the different types of maize cultivars.

\begin{tabular}{llllllll}
\hline Type & $\mathrm{ABS} / \mathrm{CS}_{0}$ & $\mathrm{DI}_{0} / \mathrm{CS}_{0}$ & $\mathrm{TR}_{0} / \mathrm{CS}_{0}$ & $\mathrm{ET}_{0} / \mathrm{CS}_{0}$ & $\mathrm{RE}_{0} / \mathrm{CS}_{0}$ & $\mathrm{PI}_{\mathrm{ABS}}$ & $\mathrm{PI}_{\text {total }}$ \\
\hline HYHS & $555.8 \pm 58.0^{\mathrm{a}}$ & $165.6 \pm 38.5^{\mathrm{a}}$ & $390.2 \pm 17.1^{\mathrm{a}}$ & $220.2 \pm 23.7^{\mathrm{a}}$ & $129.7 \pm 14.2^{\mathrm{a}}$ & $1.26 \pm 0.51^{\mathrm{ab}}$ & $1.82 \pm 0.49^{\mathrm{b}}$ \\
HYLS & $507.7 \pm 24.0^{\mathrm{b}}$ & $132.7 \pm 21.9^{\mathrm{b}}$ & $375.0 \pm 16.7^{\mathrm{ab}}$ & $216.6 \pm 19.3^{\mathrm{ab}}$ & $124.1 \pm 9.5^{\mathrm{a}}$ & $1.62 \pm 0.59^{\mathrm{a}}$ & $2.23 \pm 0.56^{\mathrm{a}}$ \\
LYHS & $509.7 \pm 25.6^{\mathrm{b}}$ & $140.1 \pm 26.1^{\mathrm{b}}$ & $369.6 \pm 20.7^{\mathrm{b}}$ & $220.5 \pm 14.2^{\mathrm{a}}$ & $127.0 \pm 9.3^{\mathrm{a}}$ & $1.61 \pm 0.48^{\mathrm{a}}$ & $2.19 \pm 0.39^{\mathrm{ab}}$ \\
LYLS & $520.6 \pm 32.5^{\mathrm{b}}$ & $157.0 \pm 31.1^{\mathrm{ab}}$ & $363.6 \pm 29.2^{\mathrm{b}}$ & $199.7 \pm 32.1^{\mathrm{b}}$ & $124.9 \pm 14.7^{\mathrm{a}}$ & $1.13 \pm 0.53^{\mathrm{b}}$ & $1.85 \pm 0.45^{\mathrm{b}}$ \\
\hline
\end{tabular}

production efficiency (NGPE, PGPE, KGPE) among the four types maize was opposite to nutrients accumulation in $100 \mathrm{~kg}$ of grains.

Leaf PSII photochemical characteristics of different maize types: The number of PSII reaction centers per cross-section $\left(\mathrm{RC} / \mathrm{CS}_{0}\right)$ of the LYLS was $6.6 \%$ lower in contrast to the other types of maize, where the HYLS was significantly higher than that of the LYLS (Fig. $3 A$ ). Absorption flux per PSII reaction center (ABS/RC) of HYHS and LYLS was significantly higher than that of other types (Fig. 3B).

Specific fluxes and quantum flux ratios are presented in Table 4 and Fig. 4; the ABS/CS 0 of the HYHS was significantly higher than that of other maize types, and the $\mathrm{DI}_{0} / \mathrm{CS}_{0}$ was significant positively correlated with $\mathrm{ABS} /$ $\mathrm{CS}_{0}$. The $\Phi_{\mathrm{Do}}\left(\mathrm{DI}_{0} / \mathrm{ABS}\right)$ of the HYHS and LYLS was 29.8 and $30.2 \%$, respectively, which was higher than that of the HYLS (26.1\%) and LYHS (27.5\%). The $\mathrm{TR}_{0} / \mathrm{CS}_{0}$ of the HY maize type was $4.4 \%$ higher in contrast to the LY maize, where the LYHS and LYLS was significantly lower than that of the HYHS. The $\Phi_{\mathrm{P}_{\mathrm{o}}}\left(\mathrm{TR}_{0} / \mathrm{ABS}\right)$ of the HYLS and LYHS was 73.9 and $72.5 \%$, respectively, which were higher than that of the HYHS (70.2\%) and LYLS (69.8\%). The $\mathrm{ET}_{0} / \mathrm{CS}_{0}$ of the HYHS and LYHS was significantly higher than that of the LYLS, whereas the $\Phi_{\mathrm{Eo}}\left(\mathrm{ET}_{0} / \mathrm{ABS}\right)$ of HYHS was $7.1 \%$ lower in contrast to the HYLS, and the
$\Phi_{\mathrm{E} 0}$ of LYHS was $11.3 \%$ higher in contrast to the LYLS. No obvious differences in $\mathrm{RE}_{0} / \mathrm{CS}_{0}$ of the different types maize were observed, and, the $\Phi_{\mathrm{Ro}}\left(\mathrm{RE}_{0} / \mathrm{ABS}\right)$ of the different types of maize was similar.

$\mathrm{PI}_{\text {total }}$ was related to the function of the "whole" linear electron transport, whereas $\mathrm{PI}_{\mathrm{ABS}}$ is related only to the electron transport to the PQ pool, both of them had been used in evaluating the functional activity of PSII. PI $\mathrm{ABS}_{\text {, }}$ $\mathrm{PI}_{\text {total }}$ of HYLS and LYHS maize were higher than the others (Table 4).

\section{Discussion}

Correlation between SPAD readings and corn grain yield: In the present study, the coefficient of determination between the SPAD readings at the silking stage and yield among 55 maize types was very low $\left(r^{2}=0.028\right)$, and there was no significant correlation (Fig. 1). Our results were similar to those of Costa et al. (2001) and Ghimire et al. (2015), who found a weak correlation between the SPAD and yields among maize cultivars. However, most researchers indicated that SPAD had a higher positive correlation with maize yields (Rostami et al. 2008, Ciampitti et al. 2012). In general, these studies established a relationship between SPAD values and yields under different $\mathrm{N}$ application rates within a single maize genotype. Further, several studies found a high SPAD-yield correlation across different 


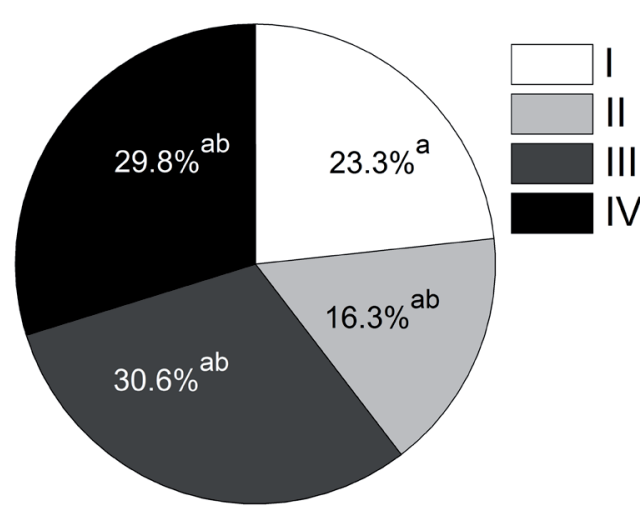

HYHS

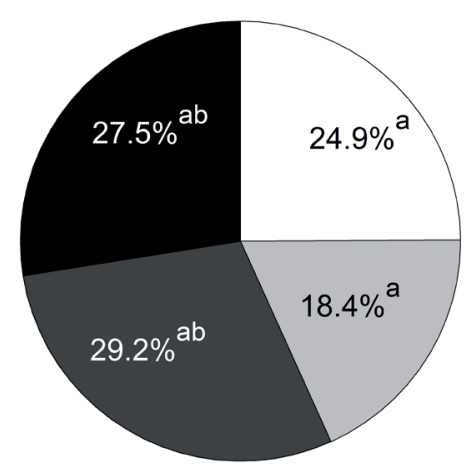

LYHS

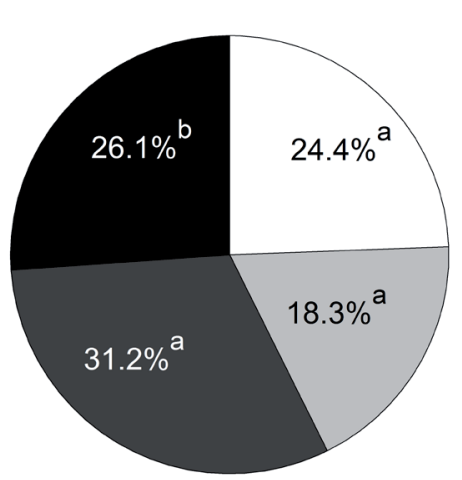

HYLS

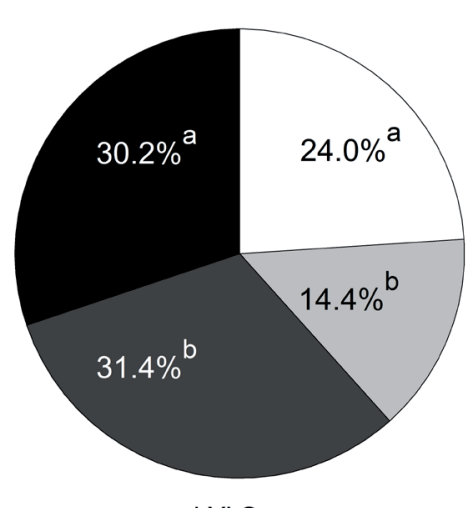

LYLS

Fig. 4. The flux ratios in different types of maize cultivars. Circled areas represent the relative $A B S / \mathrm{CS}_{0}, \mathrm{I}=\Phi_{\mathrm{Ro}}$ (quantum yield for the reduction of end acceptors of PSI per photon absorbed at $\mathrm{t}=0$ ), $\mathrm{I}+\mathrm{II}=\Phi_{\mathrm{Eo}}$ (quantum yield for electron transport at $\mathrm{t}=0$ ), I $+\mathrm{II}+\mathrm{III}$ $=\Phi_{\mathrm{P}_{\mathrm{o}}}$ (maximum quantum yield of primary photochemistry at $\left.\mathrm{t}=0\right), \mathrm{IV}=\Phi_{\mathrm{Do}_{\mathrm{o}}}($ quantum yield for energy dissipation at $\mathrm{t}=0)$. Different letters in the I, II, III and IV, respectively, denote significant differences of $\Phi_{\mathrm{Ro}}, \Phi_{\mathrm{Eo}}, \Phi_{\mathrm{P}_{\mathrm{o}}}, \Phi_{\mathrm{D}_{\mathrm{o}}}$ according to the LSD post-hoc test ( $\left.p<0.05\right)$ between the different types of maize cultivars. Values are means $(n=3)$.

maize cultivars (Waskom et al. 1996, Cai et al. 2010). However, the selected number of varieties for these studies was insufficient $(<10)$. Additionally, Costa et al. (2001) stated that the SPAD-yield relationships were stronger for the more conventional hybrids. Therefore, previous viewpoints might be correct; however, not as relates to modern maize cultivars.

The use of relative SPAD as a $\mathrm{N}$ nutrition diagnosis index was not affected by the cultivar, and the correlation coefficients for the relative SPAD vs. the relative yield were greater than SPAD vs. yield (Hawkins et al. 2007, Ziadi et al. 2008). It was concluded that the SPAD meter was more useful as a diagnostic aid, rather than a N-management tool for corn (Rashid et al. 2005).

Nutrients absorption and utilization response to leaf color and maize yield: As there was no obvious correlation between the SPAD and corn grain yields, the 55 maize cultivars could be divided into four types, depending on the average of SPAD and yields of all cultivars (Table 1). The percentage of each maize type was approximately 25\% (Table 1), which indicated that leaf color may not be a significant indicator for modern maize producers.

The accumulation of dry matter was deemed to be an important basis for corn yield formation (Tollenaar et al.
2006). In the present study, the overall plant dry matter of high-yield maize varieties was significantly higher than that of the low-yield cultivars (Fig. 2). Besides, the leaf dry matter of the high-yield maize cultivars was significantly higher than that of the low-yield cultivars; however, no obvious or significant differences in the stem dry matter among the different maize types was observed (Fig. 2). Also, previous studies considered that the development of leaves was positively related to corn grain yields (de Toledo Alvim et al. 2010). Although, the plant dry matter of low-yield maize was less than that of high-yield maize, the plant $\mathrm{N}$ and $\mathrm{P}$ uptake among different types of maize was similar (Table 2). Different from $\mathrm{N}$ and $\mathrm{P}$, higher $\mathrm{K}$ accumulation promoted the transport of $\mathrm{CO}_{2}$ assimilation products from vegetative organs to reproductive organs (Pan et al. 2017), which might be another reason for the high yield of maize. The $\mathrm{N}$ and $\mathrm{P}$ absorbed within the highyield maize were primarily allocated to grain production, whereas for low-yield maize, the $\mathrm{N}$ was retained in the straw to a higher degree, especially for LYHS maize (Tables 2, 3). Retention of $\mathrm{N}$ in the leaves and stems might reflect an inability for $\mathrm{N}$ remobilization from vegetative parts of the plant (Ning et al. 2013, Antonietta et al. 2014). Rubisco was an important leaf $\mathrm{N}$ temporary storage site, in order to recycle nutrients, the reduction of 
it was a necessary consequence (Wei et al. 2015, Mu et al. 2016). And, degradation of Rubisco was triggered by reactive oxygen species, which was accompanied with plant senescence (Hörtensteiner and Feller 2002). Hence, the senescence rate of LYHS maize might be the slowest during post-silking, and leaf possessing a stay-green trait.

The N, P, and K accumulations in $100 \mathrm{~kg}$ of low-yield maize grains were significantly higher than that of highyield maize (Table 3 ). In order to achieve an equivalent production level, low-yield maize typically consumed far more chemical fertilizer than did high-yield maize.

Effect of leaf color on photosynthetic characteristics of maize at different yield levels: For the present study, the Chl $a$ fluorescence transient, recorded at a high temporal resolution, was analyzed by the JIP-test in order to quantify the PSII behavior in different types of maize. $\mathrm{PI}_{\mathrm{ABS}}, \mathrm{PI}_{\text {total }}$ in HYLS and LYHS was higher, indicating a greater integral functional activity of PSII, PSI, and intersystem electron transport chain (Goltsev et al. 2016). Generally, $\mathrm{PI}_{\mathrm{s}}$ was used to characterize plant resistance to various environmental stresses, and its sensitivity was higher than $\Phi_{\mathrm{Po}}$ (Stirbet et al. 2018); however, $\mathrm{PI}_{\mathrm{s}}$ seemed not to determine grain yields individually. In the absence of environmental stress, parameters determining yield were the leaf area (assuming that the leaf thickness was consistent, the leaf dry mass determined the leaf area; Fig. 2), $\mathrm{PI}_{\mathrm{s}}$ and absorption flux per CS.

At the high yield level, a higher absorption flux per $\mathrm{CS}\left(\mathrm{ABS} / \mathrm{CS}_{0}\right)$ was accompanied by a high percentage of dissipated energy $\left(\Phi_{\text {Do }}\right)$ within HYHS maize, which reduced the difference in $\mathrm{TR}_{0} / \mathrm{CS}_{0}$ between HYHS and HYLS (Table 4, Fig. 4). At the low yield level, the density of reaction centers of LYLS maize was lower than that of the LYHS maize (Fig. 3A); however, its absorption flux per CS was higher than that of the LYHS maize (Table 4). These results suggested that a greater absorption efficiency of light energy per RC (ABS/RC) of the LYLS made up for the insufficient quantity of RC (Fig. $3 B$ ). Additionally, we detected that the electron transport flux per $\mathrm{CS}\left(\mathrm{ET}_{0} / \mathrm{CS}_{0}\right)$ of high-SPAD maize was higher than that of low-SPAD maize at the low yield levels (Table 4), which might be related to the increased percentage of non- $\mathrm{Q}_{\mathrm{B}}$-reducing reaction centers (Strasser et al. 2004).

Conclusion: No significant correlation between leaf SPAD readings and yields across different maize cultivars was observed, and high-yielding maize possessed greater accumulation and utilization of $\mathrm{N}, \mathrm{P}$, and $\mathrm{K}$ nutrients than low-yielding maize. Furthermore, dry matter accumulation in leaves, $\mathrm{PI}_{\mathrm{s}}\left(\mathrm{PI}_{\mathrm{ABS}}\right.$ or $\left.\mathrm{PI}_{\text {total }}\right), \mathrm{ABS} / \mathrm{CS}_{0}$ in a sequence determined the capacity for achieving high yields in maize. At the high yield level, both the energy absorption flux and dissipation ratios were enhanced with increased chlorophyll, which narrowed the difference of trapped transport flux between high-SPAD and low-SPAD maize. At the low yield level, the density of the PSII reaction centers of low-SPAD maize was reduced; however, the higher absorption flux per reaction center made up for this deficit.

\section{References}

Antonietta M., Fanello D.D., Acciaresi H.A. et al.: Senescence and yield responses to plant density in stay green and earliersenescing maize hybrids from Argentina. - Field Crop. Res. 155: 111-119, 2014.

de Toledo Alvim K.R., de Brito C.H.D., Brandão A.M. et al.: Quantification of leaf area and defoliation effect in corn crop components. - Ciênc. Rural 40: 1017-1022, 2010.

Appenroth K.J., Stöckel J., Srivastava A. et al.: Multiple effects of chromate on the photosynthetic apparatus of Spirodela polyrhiza as probed by OJIP chlorophyll a fluorescence. Environ. Pollut. 115: 49-64, 2001.

Boegh E., Soegaard H., Broge N. et al.: Airborne multispectral data for quantifying leaf area index, nitrogen concentration, and photosynthetic efficiency in agriculture. - Remote Sens. Environ. 81: 179-193, 2002.

Cai H.G., Mi G.H., Chen F.J. et al.: Genotypic variation of leaf SPAD value, nitrogen and nitrate content in maize. - Plant Nutr. Fertil. Sci. 16: 866-873, 2010.

Ciampitti I.A., Zhang H., Friedemann P. et al.: Potential physiological frameworks for mid-season field phenotyping of final plant nitrogen uptake, nitrogen use efficiency, and grain yield in maize. - Crop Sci. 52: 2728-2742, 2012.

Costa, C., Dwyer, L.M., Dutilleul, P. et al.: Inter-relationships of applied nitrogen, SPAD, and yield of leaf and non-leafy maize genotypes. - J. Plant Nutr. 24: 1173-1194, 2001.

Errecart P.M., Agnusdei M.G., Lattanzi F.A. et al.: Leaf nitrogen concentration and chlorophyll meter readings as predictors of tall fescue nitrogen nutrition status. - Field Crop. Res. 129: 46-58, 2012.

Goltsev V.N., Kalaji H.M., Paunov M. et al.: Variable chlorophyll fluorescence and its use for assessing physiological condition of plant photosynthetic apparatus. - Russ. J. Plant Physl+ 63: 869-893, 2016.

Ghimire B., Timsina D., Nepal J.: Analysis of chlorophyll content and its correlation with yield attributing traits on early varieties of maize (Zea mays). - J. Maize Res. Dev. 1: 134$145,2015$.

Havaux M., Tardy F.: Thermostability and photostability of photosystem II in leaves of the chlorina-f 2 barley mutant deficient in light-harvesting chlorophyll $a / b$ protein complexes. - Plant Physiol. 113: 913-923, 1997.

Hawkins J.A., Sawyer J.E., Barker D.W. et al.: Using relative chlorophyll meter values to determine nitrogen application rates for corn. - Agron. J. 99: 1034-1040, 2007.

Hörtensteiner, S., Feller U.: Nitrogen metabolism and remobilization during senescence. - J. Exp. Bot. 53: 927-937, 2002.

Li H., Zheng Q., Zhang J., et al.: The analysis of determining factors and evaluation of tolerance to photoinhibition in wheat (Triticum aestivum L.). - Photosynthetica 55: 69-76, 2017.

Lindsey A.J., Steinke K., Rutan J. et al.: Relationship of DGCI and SPAD values to corn grain yield in the eastern corn belt. - Crop For. Turfgrass Manage. 2: 184, 2016.

Lin F.F., Qiu L.F., Deng J.S. et al.: Investigation of SPAD meterbased indices for estimating rice nitrogen status. - Comput. Electron. Agr. 71: S60-S65, 2010.

Liu K.L., Li Y.Z., Yu P.L. et al.: Estimating grain yield based on BSW and SPAD at grain filling stage in double rice cropping system of China. - Int. J. Agric. Biol. 18: 889-894, 2016.

Li Y., Ren B.B., Gao L.M. et al.: Less chlorophyll does not necessarily restrain light capture ability and photosynthesis in a chlorophyll-deficient rice mutant. - J. Agr. Crop Sci. 199: 49-56, 2013.

Mielke M.S, Schaffer B., Li C.: Use of a SPAD meter to estimate chlorophyll content in Eugenia uniflora L. leaves as affected 
by contrasting light environments and soil flooding. Photosynthetica 48: 332-338, 2010.

$\mathrm{Mu}$ X.H., Chen Q.W., Chen F.J. et al.: Within-leaf nitrogen allocation in adaptation to low nitrogen supply in maize during grain-filling stage. - Front. Plant Sci. 7: 699, 2016.

Ning P., Li S., Yu P. et al.: Post-silking accumulation and partitioning of dry matter, nitrogen, phosphorus and potassium in maize varieties differing in leaf longevity. - Field Crop. Res. 144: 19-27, 2013.

Pan Y.H., Lu Z.F., Lu J.W. et al: Effects of low sink demand on leaf photosynthesis under potassium deficiency. - Plant Physiol. Bioch. 113: 110-121, 2017.

Paponov I.A., Engels C.: Effect of nitrogen supply on leaf traits related to photosynthesis during grain filling in two maize genotypes with different N efficiency. - J. Plant Nutr. Soil Sc. 166: 756-763, 2003.

Polle J.E.W., Benemann J.R., Tanaka A. et al.: Photosynthetic apparatus organization and function in the wild type and a chlorophyll $b$-less mutant of Chlamydomonas reinhardtii. Dependence on carbon source. - Planta 211: 335-344, 2000.

Qi W.Z., Chen X.L., Liu P. et al.: [Characteristics of dry matter, accumulation and distribution of N, P and $\mathrm{K}$ of super-highyield summer maize.] - Plant Nutr. Fertil. Sci. 19: 26-36, 2013. [In Chinese]

Rashid M.T., Voroney P., Parkin G.: Predicting nitrogen fertilizer requirements for corn by chlorophyll meter under different $\mathrm{N}$ availability conditions. - Can. J. Soil Sci. 85: 149-159, 2005.

Rostami M., Koocheki A.R., Mahallati M.N. et al.: Evaluation of chlorophyll meter (SPAD) data for prediction of nitrogen status in corn (Zea mays L.). - Am.-Euras. J. Agric. Environ. Sc. 3: 79-85, 2008.
Stirbet A., Lazár D., Kromdijk J. et al.: Chlorophyll $a$ fluorescence induction: Can just a one-second measurement be used to quantify abiotic stress responses? - Photosynthetica 56: 86104, 2018.

Strasser R.J., Tsimill-Michael M., Srivastava A.: Analysis of the chlorophyll a fluorescence transient. - In: Papageorgiou G. and Govindjee (ed.): Chlorophyll Fluorescence: A Signature of Photosynthesis. Pp. 1-47. KAP Press, Netherlands 2004.

Tetali S.D., Mitra M., Melis A.: Development of the lightharvesting chlorophyll antenna in the green alga Chlamydomonas reinhardtii is regulated by the novel Tlal gene. Planta 225: 813-829, 2007.

Thomas H., Smart C.M.: Crop that stay green. - Ann. Appl. Biol. 123: 193-219, 1993.

Tollenaar M., Deen W., Echarte L. et al.: Effect of crowding stress on dry matter accumulation and harvest index in maize. - Agron. J. 98: 930-937, 2006.

Tong S.Y., Song F.B., Xu H.W.: [Correlation between variations of SPAD value of leaf at different position and biomass of maize.] - J. Nucl. Agr. Sci. 22: 869-874, 2008. [In Chinese]

Waskom R.M., Westfall D.G., Spellman D.E. et al.: Monitoring nitrogen status of corn with a portable chlorophyll meter. Commun. Soil Sci. Plan., 27: 545-560, 1996.

Wei S.S., Wang X.Y., Zhang J.W., et al.: The role of nitrogen in leaf senescence of summer maize and analysis of underlying mechanisms using comparative proteomics. - Plant Sci. 233: 72-81, 2015.

Ziadi N., Brassard M., Bélanger G. et al:: Chlorophyll measurements and nitrogen nutrition index for the evaluation of corn nitrogen status. - Agron. J. 100: 1264-1273, 2008.

(C) The authors. This is an open access article distributed under the terms of the Creative Commons BY-NC-ND Licence. 